\title{
DEVELOPING INTERCULTURAL EDUCATION
}

\author{
Marijanca Ajša VIŽINTIN
}

COBISS 1.02

\section{ABSTRACT \\ Developing Intercultural Education}

The paper discusses the role of teachers in the inclusion of migrant students and provides some suggestions for the active engagement of teachers in developing intercultural education, with examples from Slovenia. To support teachers who develop intercultural competence among all students, it is important to include concrete learning objectives in the syllabuses, in the framework of which teachers will be able to teach about social diversity. It will also be necessary to introduce content about multiethnic, multilingual, and multireligious society into the academic programmes, so that (future) teachers are more prepared for a diverse school environment and the development of an intercultural society.

KEY WORDS: immigrant children, refugees, economic migrants, prejudices, active citizenship, integration, inclusion, teachers

\section{IZVLEČEK}

\section{Razvoj medkulturne vzgoje in izobraževanja}

Prispevek odpira vprašanje o vlogi učiteljev pri vključevanju učencev priseljencev ter navaja predloge za aktivno delovanje učiteljev pri razvoju medkulturne vzgoje in izobraževanja (s primeri iz Slovenije). Da bi bil šolski sistem v podporo učiteljem, ki razvijajo medkulturno zmožnost med vsemi učenci, je treba v učne načrte dodati konkretne učne cilje, v okviru katerih bodo učitelji znotraj učnih vsebin lahko poučevali o raznoliki družbi. Vsebine o večetnični, večjezični, večverski družbi bi bilo nujno vnesti tudi v študijske programe, da bodo (bodoči) učitelji bolje pripravljeni na raznoliko šolsko realnost in soustvarjanje medkulturne družbe.

KLJUČNE BESEDE: otroci priseljenci, begunci, ekonomski migranti, predsodki, aktivno državljanstvo, vključevanje, učitelji

$\mathrm{PhD}$ in Education, research fellow at the Slovenian Migration Institute, Research Centre of the Slovenian Academy of Sciences and Arts (ZRC SAZU), Novi trg 2, SI-1000 Ljubljana; vizintin@zrc-sazu.si 


\section{INTRODUCTION}

Although a lot of projects have been carried out and some changes have been made in the past few years in the area of inclusion of migrant children in Slovenia, there are still many issues to be addressed. These include how to define intercultural education or intercultural competence as one of its important criteria, knowing that "the implementation of intercultural education in practice requires teachers with intercultural competence. However, there seems to be no standard definition of this concept" (Bešter, Medvešek 2016: 30), and "a global understanding of intercultural competence does not yet exist" Boecker (2008: 12). 'But instead of trying to find the best definition of intercultural competence, this paper highlights some perspectives on the roles different stakeholders should play in order to develop intercultural education. It employs statistical data on the number of children of economic migrants and refugees who have come to Slovenia in the last few years and introduces some new intercultural approaches that schools in Slovenia have developed for better inclusion. It also makes some recommendations on what teachers can do by themselves until more specific intercultural guidelines are introduced in school curricula.

\section{THE NEED FOR INTERCULTURALITY IN SYLLABUSES}

In order for the school system to support teachers in developing intercultural competence among all students, it is important to add concrete learning goals to the syllabuses, in the framework of which teachers can teach about social diversity, overcoming prejudices and intercultural dialogue. We have to improve the case "that a teacher's intercultural competence is mostly the result of the individual's education, training, openness and efforts rather than of specific systematic incentives and support" (Bešter, Medvešek 2016: 42-43). This is not only a task for teachers, but especially for universities which train future teachers, the Ministry of Education, Science and Sport, which is responsible for life-long learning among already employed teachers, and the commissions tasked with revamping the syllabuses.

The emphasis is on intercultural education as a part of the regular curriculum, where interculturality is a principle and not a special pedagogic discipline. Klara Skubic Ermenc (2007: 129; 2010: 272-273) understands interculturality as a pedagogical-didactic principle. This means that the aforementioned principle is applied to the planning, implementation and evaluation of education in such a way that it supports

1 Romana Bešter and Mojca Medvešek (2016: 30-32), drawing from a model introduced by Darla K. Deardorff and upgraded by Malte C. Boecker, describe intercultural competence as consisting of four dimensions: 1) attitudes towards others/those who are different; 2 ) knowledge and understanding as well as specific skills; 3 ) intercultural reflection (which represents the desired internal outcome) and 4) constructive interaction (which represents the desired external outcome). For more about intercultural competence(s) see Vrečer 2011, Huber 2012 etc. 
a change in the existing hierarchical relations between the dominant ethnic/cultural majority and the subordinate ethnic/cultural minority groups in the education system. In this way, it enhances the equity of real opportunities for education, the maintaining of various identities, and the development of solidarity towards ethnic and cultural minorities. Interculturality as a pedagogical-didactic principle encourages the following: the development of a (more pronounced) attitude of equality with regard to other cultures/ethnic groups, an attitude towards the other as an equal and not as a deficient citizen, trailblazing with a pedagogical process which enables higher achievements in minority groups, and the development of common values. It is interesting to note that interculturality is a principle and not a separate pedagogic discipline. In pedagogy, a principle is a guideline for teaching which directs the planning, implementation, and evaluation of the class, which means that it permeates the entire educational process. In order for the principle of interculturality to truly come to life, it must become part of the so-called "real school curriculum", which means the connection of the formal (official) curriculum (legislation, rules, educational programmes, curricula, textbooks, pedagogical-didactic guidelines, etc.) to the entire practice of pedagogy, including human relations, as well as the selection and interpretation of school knowledge (the so-called "hidden curriculum"), because only "several similar measures provide more opportunity for reaching the goal. The less the measures are unified, the less there is a possibility for them to become effective" (Skubic Ermenc 2007: 129). The White Paper on Intercultural Dialogue (2008) also pointed out how significant it is that such contents are included in syllabuses to provide a basis on which teachers can actually teach: ${ }^{2}$

Teacher-training curricula need to teach educational strategies and working methods to prepare teachers to manage the new situations arising from diversity, discrimination, racism, xenophobia, sexism and marginalisation and to resolve conflicts peacefully, as well as to foster a global approach to institutional life on the basis of democracy and human rights and create a community of students, taking account of individual unspoken assumptions, school atmosphere and informal aspects of education. (White Paper on Intercultural Dialogue 2008: 32)

In Slovenia, the current syllabuses are being analysed in order to identify the discriminatory practices they include. The results of this analysis should be taken into account in the new syllabuses. Ksenija Šabec (2016: 140) has found that the Slovenian geography textbooks "contribute to legitimizing the ethnic and 'racial' status quo permeated with ethnocentric stereotypes, negative representations and racist perceptions of the 'other'." Mojca Peček and Irena Lesar (2006: 187) draw attention to the fact that Slovenian teaching materials do not take into account the characteristics

2 If content about migration, refugees, prejudices, intercultural dialogue etc. are not present in syllabuses, then only teachers with intercultural competence and who perceive the need to acquaint their pupils with these topics will include them in their teaching. 
and distinctiveness of minority communities and that primary-school syllabuses include practically no content related to immigrants. This has also been evidenced by an analysis of the materials for teaching Slovenian language and literature. Janja Žitnik Serafin (2014) discovered that "they include no representatives of various ethnic groups in Slovenia and immigrant authors" (Žitnik Serafin 2014: 223). Similar analyses should be conducted for all syllabuses, preferably in cooperation with immigrants (Vižintin 2016). In addition to the revamping of syllabuses, it is necessary to include content on multicultural society, multilingualism, multiethnicity and multireligiosity in the academic programmes of the faculties of education and arts. This will allow future teachers to be better prepared for a school environment in which pupils speak different mother tongues.

With their knowledge and attitude, teachers have a substantial influence on the successful inclusion of immigrant and refugee children, but are insufficiently aware of this (Peček Čuk, Lesar 2006; Nieto, Bode 2008). Teachers need additional training in the areas of inclusion of immigrant and refugee children, intercultural education (Grant, Sleeter 2007; Skubic Ermenc 2010; Portera 2011; Vižintin 2014, 2017) and the development of (their own) intercultural competence. In the $21^{\text {st }}$ century the inclusion of immigrant and refugee children is still perceived as something extraordinary and new - unrelated to the historical experiences of Slovenian refugees in the $20^{\text {th }}$ century and the continual Slovenian economic migrations ${ }^{3}$ from the mid- $19^{\text {th }}$ century on (Drnovšek 2012; Milharčič Hladnik 2015; Žitnik Serafin 2015; Žitnik Serafin, Kalc 2017). Furthermore, Slovenia is already a multicultural, multilingual and multireligious country in which Slovenian citizens live together with members of the Italian, Hungarian and Romani minorities, numerous ethnicities from the territory of former Yugoslavia (Žitnik Serafin 2012; Dimkovska 2014; Kržišnik Bukić, Josipović 2014) and other immigrants. Migrations were and are part of the European experience. "European societies are not bipartite, consisting of indigenous and immigrant people, but constitute complex networks with multidimensional identities, sharing differences and similarities" (Rey-von Allmen 2011: 43). Europe changed from a continent of emigration (more than 40-50 million people emigrated from Europe between the mid- $19^{\text {th }}$ century and the mid- $20^{\text {th }}$ century) to a continent of immigration in the second half of the $20^{\text {th }}$ century (Castles, Miller 2009; Scheffer 2011), moving from an

3 Slovenians have always been and still are economic migrants. In the last five years, 14,000 people a year emigrated from Slovenia and approximately the same number of people immigrated to Slovenia. Data for 2014: 14,300 people emigrated from Slovenia, of whom 8,100 were Slovenian citizens and 6,200 were foreign citizens. $74 \%$ of Slovenian citizens moved to other EU-28 countries, most of them to Austria (28\%) and Germany (20\%), followed by Switzerland, Croatia and the UK. In 2014, 13,846 people immigrated to Slovenia. Although the emigration of tertiary educated Slovenians is emphasised, statistical data show that most of the emigrants are secondary-school graduates and that the education of emigrants and immigrants in 2013 was similar: more than half of the emigrants from Slovenia and immigrants to Slovenia were secondary-school graduates, only $21 \%$ of emigrants and $15 \%$ of immigrants had tertiary education, the rest had primary education (Socioeconomic Characteristics of International Migrants, 2013; Migration Changes, 2014). 
assimilatory to an integrative concept of including immigrants in society, in which numerous culturally mixed people with hyphenated identity coexist (Sedmak 2015; Milharčič Hladnik 2015).

But although "migration is an ancient phenomenon, the question of peaceful coexistence remains as yet unresolved. The word 'foreign' is commonly associated with negative or even threatening aspects" (Portera 2011: 15). The obstacles hindering inclusion include prejudices (Ule 2005; Šabec 2006), Eurocentric syllabuses (Skubic Ermenc 2007; Šabec 2015) and insufficient connection with parents or organisations in the local community that can offer the school support (Vižintin 2015). Immigrant children are included in classes but are passive, not active enough (Budinoska 2013). Teachers are insufficiently aware of the possibility of developing intercultural competence within the teaching process, for example in all language and literature classes (Vižintin 2014, 2017; Mikolič 2016), and other school subjects such as history, geography, etc. Teachers are also not sufficiently aware that every teacher is responsible for the acquisition of the specialised language in their class (Bešter Turk 2011). But every teacher has an impact on the successful inclusion of immigrant children and developing intercultural education.

\section{CHILDREN OF IMMIGRANTS AND REFUGEES IN SLOVENIA}

In the 2010/11-2014/15 school years, around a thousand immigrant children were enrolled in Slovenian primary schools (6-14 age group) for the first time, and around 300-400 were enrolled in secondary schools (15-18 age group). In the 2010/112014/15 school years they mostly (81\%) came from the countries of former Yugoslavia (Bosnia and Herzegovina, Kosovo, Macedonia, Serbia, Croatia) (Banjac 2015). In the $21^{\text {st }}$ century, their parents came to Slovenia mostly for employment, and the children consequently on the basis of family reunification. By April of the 2015/16 school year, these children were joined by refugee children, around 40 primary and 20 secondary school pupils according to the data of the Ministry of Education, Science and Sport of the Republic of Slovenia. Refugee children live in the asylum centre (if accompanied) or in crisis centres around Slovenia (if unaccompanied). In the framework of the EU refugee relocation scheme, Slovenia is supposed to take in around 600 people, including children. According to the Ministry of Internal Affairs, 19,889 asylum applications were filed and 393 applicants were granted asylum in Slovenia in the period 1995-2015, which means that in 21 years the Republic of Slovenia granted asylum to $1.97 \%$ of applicants (Statistični podatki o tujcih v Sloveniji 2015, 2016). In 2015 and 2016, around half a million refugees crossed Slovenia, fleeing the war in Syria, the overcrowded refugee camps in Jordan, Lebanon and Turkey and the ethnic, religious and sexual violence in Afghanistan, Iraq, Iran and other Middle-Eastern and African countries. According to the data of the Ministry of Internal Affairs, 141 of the 277 applications in 2015 were filed by refugees who came 
to Slovenia along the so-called Balkan route. In 2015, Slovenia granted asylum to 45 persons (or $16.2 \%$ of 277 seekers). In 2016, Slovenia granted asylum to 170 persons (or $13 \%$ of 1,308 seekers) ${ }^{4}$ (Ibid).

In the second half of the 20th century and at the beginning of the 21st century, the strongest prejudices in Slovenia were directed against the largest group of immigrants, those from Bosnia and Herzegovina. ${ }^{5}$ Prejudices against groups of immigrant children are associated with lower teacher expectations (Peček Čuk, Lesar 2006). "Lower teacher expectations for particular racial or ethnic groups are based on negative racial or ethnic prejudices. Teachers, like all people, often are not aware of their prejudices; thus they may not be aware of their lower expectations for some students" (Bennett 2011: 22-23). Prejudices are preserved and intensified most

when they are not discussed, even less problematised, but in order to deconstruct and eliminate prejudices as micro-ideologies of the everyday world, which are usually firmly entrenched in the existing mechanisms of power, we need to do more than only critically reflect on them. Although this is doubtlessly the first step towards abolishing the power of prejudices, we have to reveal, challenge and criticise the mechanisms of their emergence and operation and on the collective level establish the competencies of a critical distance to one's own perceptions about other people, while at the same time develop means for their elimination on the formal legal level. (Šabec 2006: 21)

There has been an increase in intolerance and a strengthening of the prejudices against Albanian-speaking children and their parents coming to Slovenia in the $21^{\text {st }}$ century mostly from Kosovo, Macedonia, occasionally Montenegro, and a very small number from Albania. The intolerance towards Albanian-speaking immigrants is probably a consequence of an increased number of Albanian-speaking children enrolling in Slovenian schools, unfamiliarity with the Albanian language, the new immigrants not speaking an intermediary language (which means that teachers cannot draw on Serbo-Croatian or other foreign languages), and a feeling of powerlessness due to insufficient professional knowledge about the inclusion of immigrant children.

4 Of the 277 asylum seekers in 2015, 231 were male and 46 female. Most of them came from Afghanistan (48 or 17.3\%), Iraq (43 or 15.5\%), and less from Iran (35), Kosovo (28), Pakistan (25), Syria (17), Ukraine (14) etc. In 2016, 1,308 persons applied for asylum in Slovenia, 1,085 men and 223 women; 1,184 refugees came during the so-called refugee wave. The largest share of asylum seekers came from Afghanistan (419 or 32\%), Syria (281 or $21.4 \%)$, Iraq (120 or 9\%) and Pakistan (104 or 8\%). Less than 80 people came from Iran (78), Turkey (60), Morocco (39), Algeria (42), Eritrea (28), Serbia (21), Kosovo (18), Libya (17), Tunisia (11) etc. (Statistični podatki o tujcih v Sloveniji [Statistical Data on Foreign Nationals in Slovenia] 2015, 2016).

5 Some examples of prejudices: immigrants from Bosnia and Herzegovina, also called "Southerners", are supposedly "lazy and are bleeding the developed Republic of Slovenia dry" (Kentrič 2015: [46]); "stupid because their parents hit them over the head" (Pašić in Merkeš 2014: 6); while Albanian-speaking pupils are supposed to be "unmotivated, disruptive" (Vižintin 2017: 122-126). 
Refugees, people fleeing war and violence, also divided Slovenia in 2015 and 2016: on the one hand, a lot of volunteers worked at the refugee accommodation centres (Dobova, Šentilj, Vrhnika) and individual journalists (Gorazd Rečnik, Boštjan Videmšek, Ervin Milharčič Hladnik) tried to relate people's tragic life stories, while, on the other hand, the media mostly reported on the refugee wave and the politicians talked about the security question (and surrounded the country with a razor-wire fence, the so-called "technical barrier"). There was a series of protests against the settlement of refugees (in Kranj, Ljubljana, Vrhnika, Lenart, Lendava and Logatec in February 2016 and in Škofije in March 2017 etc.), sometimes countered by simultaneous protests in support of their settlement; and hate speech intensified and spread. At the same time, a series of round table discussions and conferences were held in support of the refugees (among others, at the Kranj Library, the Education Trade Union, the Ministry of Education, Science and Sport, ZRC SAZU etc.) and scientific analyses of media responses (Luthar 2017, Pajnik 2017 etc.).

With the increased number of refugees, some people in Slovenia have become more intolerant towards and fearful of refugees. Prejudices have been spreading, and teachers feel increasingly stressed due to the lack of knowledge on how to include refugee children into the existing school system. In 2016, there were widespread reports in Slovenia on the first enrolments or accommodation of refugee children being met with non-acceptance and rejection: in Logatec, the town council adopted a decision that children cannot be included in a kindergarten or a school until they learn to speak Slovene; at the student dormitory in Kranj they refused to accommodate unaccompanied refugee children because some parents were against it; in the same town, 24 teachers at a secondary school signed a statement saying that they were also against the accommodation of unaccompanied refugee children. These events showed ignorance of Slovenian legislation, since the decision adopted by the Logatec town council is contrary to law, ignorance of the Slovenian education system, which is based on an inclusive approach and enables every child to enter a Slovenian primary school regardless of the parents' status (temporary residence, permanent residence, asylum seekers, citizens), prejudices and open expressions of intolerance, a lack of competence among educational employees for the inclusion of refugee children, and the unpreparedness of the Ministry of Education, Science and Sport, which gave in to the parents' pressure and refused to accommodate unaccompanied refugee children in Kranj.

In the case of primary schools, the Slovenian Ministry of Education, Science and Sport decided on the direct inclusion of both immigrant and refugee children in classes and the simultaneous training of teachers. In practice, this means that children are included in classes immediately after they are enrolled. Direct inclusion in classes - without knowledge of the language used for instruction - is a challenge both for the teachers and the pupils. It was noted immediately upon the enrolment of the immigrant children that the teachers feel insufficiently competent for this task, with some of them suggesting that the children should attend an intensive 
course in Slovene for a few months before/when they come to school (Knez 2012; Vižintin 2017: 179-180). With the increased enrolment of refugee children, their distress or need for additional training has only intensified. Immigrant children are also directly enrolled in secondary school. Asylum seekers aged between 15 and 18 are first enrolled in a 300-hour (+100) programme that they have to complete before enrolling in regular school (Izobraževalni programi. Opismenjevanje ... 2016; Poročilo za opismenjevanje za mladoletnike brez spremstva 2017). Due to the economic circumstances and the political and economic destabilisation of countries including Syria and its neighbourhood and many African countries, the continuous influx of refugees will only increase. Teachers need to be prepared and trained for this. The asylum procedures should also be improved. According to Mateja Sedmak and Zorana Medarić (2017: 67), the "transition through the international protection procedures clearly shows the absence of a child-friendly approach as well as a lack of respect for the implementation of the best interest of the child principle. There is a lack of information regarding the border and possible return procedures."

\section{SEARCHING FOR NEW INTERCULTURAL APPROACHES IN SCHOOLS}

Neva Šlibar (2006) points out the harmfulness of not reacting in cases of expressed intolerance, non-acceptance or refusal of support, since "false tolerance, i.e. carelessness, indifference and passivity, [...] also kills" (Šlibar 2006: 23). Mojca Peček and Klara Skubic Ermenc (2016) note that: "if we want to see more radical changes, we cannot ignore attitudes, stereotypes and prejudices - either those of learners or those of teachers" (Peček, Skubic Ermenc 2016: 21). Combating racism, sexism and all forms of prejudice and discrimination is an important goal of a multicultural curriculum (Bennett 2011: 30-33), in addition to understanding multiple historical perspectives, developing cultural consciousness, intercultural competence, raising awareness of the state of the planet and global dynamics, and developing social action skills.

In the inclusion of refugee children, some Slovenian schools have drawn on their experiences gained in the inclusion of (economic) immigrant children and at the same time sought new approaches. One example of a primary school where they are aware that education is a dynamic and continuous process that demands changes in established habits, teacher training, a response to the new needs and the development of new approaches is the Koper Primary School. For several years, they have been testing different ways of achieving a more successful inclusion of immigrant children and have found that the inclusion process presents many challenges both for the children and the teachers: children need time to integrate into the new environment and support during the school year; there are various possibilities for learning the language; and teachers require continuous training in the field of intercultural education. Koper Primary School is also a (co)leader of national projects, such as Challenges of Intercultural Co-Existence 2016-2021. 
At the Livada Primary School in Ljubljana they have added new flags to their "citizenship stew" and proudly state that pupils from 32 different countries are enrolled there. For the 27 new refugee children in the 2015/16 school year, they obtained financial support, established a network of volunteers and introduced a new way of teaching Slovene, every day for one period before the start of the school day and during the first two periods, after which the children attend regular classes with their classmates (Petrovčič 2016a; Gruden 2016). At the 8 Talcev Primary School in Logatec they published papers written by their refugee children in different languages in addition to papers by other children in their 2016/17 school newspaper, and, in line with the need to communicate with Arabic-speaking pupils, they published the Slovenian-English-Arabic Dictionary for School Use (Al Dolejmi 2017). At the Bojan Ilich Primary School in Maribor, teachers, pupils and parents prepared for the arrival of three unaccompanied refugee children by learning about Afghanistan (and the wars being waged in this destabilised country due to the interference of other countries), reading In the Sea There Are Crocodiles (Geda 2012) and I Am Malala (Yousafzai, Lamb 2013), making contact with a local association which promotes intercultural understanding, Društvo Odnos, and obtaining funding for one-to-one tuition. ${ }^{6}$ As Michele Rey-von Allmen (2011: 36) stresses: "intercultural relations do not concern foreigners alone or any single group of people". This is why these schools have been successful in the inclusion of immigrant and refugee children. The workshops, projects and other activities are conducted with all the children and their parents, and not just the immigrants. Goran Popovič, the principal of the Livada Primary School in Ljubljana, is adamant: "A teacher must help a child no matter what. Because when you get such a young being, this being is not responsible for the wars or the politics or their parents' actions. Are we human beings or not?" (Petrovčič 2016: 41)

Despite the examples of good practice, teachers in Slovenia still have numerous questions about how to integrate immigrant children. A model of intercultural education (Vižintin 2014, 2017) was developed to make the inclusion of immigrant and refugee children more effective and successful for both the children and the teachers. It includes all the stakeholders involved in the integration process: pupils and parents (both immigrants and natives), educational employees (including those who have experience of emigrating themselves), the immigrants and their organisations, the local community and governmental organisations that influence the educational process and participate in the creation of an inclusive society. It does not focus merely on one particular field of inclusion (e.g., assessment, teaching Slovene as a second language), but with its seven criteria offers a comprehensive approach to inclusion: 1. interculturality as a pedagogical-didactic

6 The school's principal Štefan Muraus talked about this experience at a round table discussion entitled An Intercultural Approach to Including Migrant Children, which was part of the Conference on the Linguistic Inclusion of Immigrants into Kindergartens and Schools organised by the Ministry of Education, Science and Sport (Ljubljana, 23 September 2016). 
principle, 2. systemic support for the successful inclusion of immigrant children, 3. development of teachers' intercultural competence, 4. increasing the awareness of a multicultural society in all school subjects, 5 . development of intercultural dialogue in schools, 6. cooperation with immigrants (parents), 7. cooperation with the local community (Vižintin 2014, 2017). The Ministry of Education, Science and Sport has also addressed the need for additional teacher training related to the inclusion of immigrant children, for example in the project Only (With) Others Are We, ${ }^{7}$ conducted by ZRC SAZU, the Slovenian Migration Institute and the Educational Research Institute.

\section{What can teachers do themselves?}

As active citizens, teachers should respond to prejudices and discrimination in their (school) environments, and through their knowledge and activities promote the development of intercultural education. A significant part of this involves the development of intercultural dialogue at their educational institution and in the local community, in line with genuine diversity (multilingualism, multiethnicity, multireligiosity) and, importantly, together with the immigrants. Those teachers who develop their intercultural competence (all their life) will be most successful in fostering it in their pupils. Teachers should constantly participate in training courses and projects, and exchange examples of good practice; they should be aware of the influence of their views and expectations and the fact that it takes several years to learn the language of the new environment and integrate into it. As Malte C. Boecker (2008: 7) explains: "The more positive the attitude, the more knowledge and skills developed and the more often intercultural situations are reflected or handled constructively, the more likely it is that a higher degree of intercultural competence is achieved."

Active teachers take part in changing the existing hierarchical relations, which means that, in their (school) environment, they identify cases of (systemic, latent) discrimination, make themselves and their pupils aware of prejudices and stereotypes, endeavour to overcome them and openly oppose them. With their knowledge and actions, they, as active citizens, contribute to the changes that enable the development of an actually equal relation between different cultural, ethnical, linguistic and other communities, with the awareness that too much emphasis "is placed on the fact that people are different from each other, while forgetting the

$7 \quad$ The aim of the project Only (With) Others Are We (Le $z$ drugimi smo 2016-2021) is to train professionals and leaders in all fields of education from preschool to adult education. The project provides the following five free-of-charge 16-hour professional training courses: 1) Living the Diversity: Immigrant Inclusion, Slovene Language and Intercultural Dialogue; 2) Zero Tolerance for Violence: Challenges and Issues; 3) Respectful Communication and Conflict Management; 4) The Challenges of Modern Society in Education; 5) Intercultural Relations and Integration in Education Practice. The Only (With) Others Are We project is led by Marina Lukšič Hacin and coordinated by Marijanca Ajša Vižintin. 
basic assumption [...] - that we are first and foremost similar to each other" (Lukšič Hacin 2016: 89). In view of the growing intolerance and publically expressed prejudices, it is important that teachers respond to the racism and xenophobia in educational institutions (and their local communities). I suggest three types of activities: 1) self-study, 2) teaching students (sometimes including parents and local community), 3) dissemination of activities.

The first activity, self-study, consists of information seeking and learning. I suggest that teachers obtain as much information as possible about migration as a constant process, about prejudices and their characteristics, the reasons for the arrival of the children of economic migrants and refugees and the conditions in the countries that their pupils come from, and about Slovenians abroad (Slovenians as emigrants and refugees), etc. They can do that on their own or they can search for additional training courses dedicated to those goals, for example Only (With) Others Are We. In the process of learning and obtaining as much authentic information as possible, it is useful to find the existing materials about these topics, which will help the teachers conduct workshops and carry out other activities with children (and sometimes with their parents). Carl A. Grant and Christine E. Sleeter (2007) suggest the following resources for teachers: books for children and young people, internet resources, local resources and the pupils themselves. I also suggest participation in public events (conferences, round table discussions, readings) that present the topics of migration, refugees, practices of inclusion and exclusion, discrimination or people's life stories and personal experiences.

Good teachers choose and use resources thoughtfully rather than overrelying on them. In addition, the best teachers are not only ongoing learners themselves, but also inveterate collectors. Over time, their classrooms become well stocked with materials, and usually they have become active in community or professional activities. Also, they seek out other teachers and librarians with whom to share resources, and varied venues where they can locate new resources. They assume that good resources exist and can be found. (Grant, Sleeter 2007: 182)

The second activity is teaching students. It includes active engagement in educational processes, since there are only a few intercultural goals in the school curricula. It is important to transfer knowledge to pupils (and sometimes to their parents and the local organisations) and at the same time to learn from them and their experiences. There are different ways to teach about diversity and develop intercultural competence: one of the possibilities is conducting intercultural workshops with the pupils in class, if possible in the framework of the educational process, during school time, in order to raise awareness about the processes of migration, refugees and prejudices. The next possibility is conducting public intercultural events at the educational institutions, to which all pupils, teachers and parents are invited. The focus here should be on positive examples and overcoming prejudices, and not 
on their reinforcement. ${ }^{8}$ It is important to cooperate with the immigrants as active participants in and creators of intercultural lessons or intercultural events. When teachers obtain enough knowledge and experience, they can also organise talks or round table discussions with people who have a migrant or refugee experience (in a smaller group). Let us give immigrant parents, both men and women, the opportunity to show us what they know, what they do for a living, how they spend their free time; in addition to cooks and housewives, their ranks undoubtedly also include literature and other arts experts, sports fans, scientists, researchers, doctors, nurses, entrepreneurs etc., of both sexes. The time has come to overcome

today's imposed hegemonic discourse about the image of migrant women who, as passive victims of familial and cultural circumstances, need above all protection and care, and present their experiences, choices and activities within social hierarchies, differentiations and control as relevant and significant for everybody, not just them. (Milharčič Hladnik 2016: 44)

In Slovenia, there are many people with refugee experience, people who fled the war and ethnic violence in Bosnia and Herzegovina at the end of the 1990s and in Kosovo at the beginning of the $21^{\text {st }}$ century. They live among us and some are prepared to talk about their refugee experience. There are even more economic migrants who are prepared to share their experience of migrating and integration - this is not a one-time event that ends with settlement in the receiving country, but a long process that can take years. Through these (and other) suggested activities, pupils also learn how to be active citizens from their teachers: "Educators at all levels play an essential role in fostering intercultural dialogue and in preparing future generations for dialogue. Through their commitment and by practising with their pupils and students what they teach, educators serve as important role models" (White paper on Intercultural Dialogue 2008: 32).

Lastly, it is important that the pupils are active; that they themselves seek information under the teacher's mentorship and based on their encouragement. Under the teacher's mentorship, pupils can seek information in their school or local community, identify people with immigrant experience, including among their relatives who migrated from Slovenia abroad, conduct interviews with them, write a paper about their activities, invite them to present their life experience in class etc. As Vesna Mikolič says, students

8 Migrants very often only present their cuisine or folklore in the name of multi- or interculturality at schools, and in this way we actually reinforce the entrenched stereotypes and prejudices - however, during the lessons, they rarely speak about the cultural, economic, scientific and other achievements which the members of migrant communities contributed to the development of humanity or in local communities (Vižintin 2015: 128). 
should be involved in the cultural reality of their surroundings instead of learning about abstract intercultural values. During classwork, students should independently explore new sources of information about different cultural backgrounds, gather information, compare materials, discuss similarities and differences, and validate their opinions about various cultures through projects. (Vesna Mikolič 2016: 90)

The last activity is dissemination. It is important that teachers write and report about their experiences and that that information is spread and exchanged. Other teachers can learn from the published results, use their experiences and build on them in accordance with the experiences and needs in their local community. Teachers can report on their active engagement in local newspapers, on the local radio, and in professional and scientific journals. It is important that information about the active engagement of teachers who contribute to a respectful and intercultural society is spread.

\section{CONCLUSION}

This paper gives various examples from Slovenian schools that have found new approaches to intercultural education. At the Koper Primary School, teachers receive continuous training in the field of intercultural education and they participate in or lead national projects. At the Livada Primary School in Ljubljana, they have enrolled pupils from different 32 countries. At the 8 Talcev Primary School in Logatec, they published papers by refugee children in different languages in addition to papers by other children in their 2016/17 school newspaper, and, in line with the need to communicate with Arabic-speaking pupils, they published the Slovenian-EnglishArabic Dictionary for School Use (AI Dolejmi 2017). At the Bojan Ilich Primary School in Maribor, teachers, pupils and their parents prepared for the arrival of three unaccompanied refugee children by learning about Afghanistan, reading novels about children's refugee experiences and getting support in the local community. At these schools, they understand that we need to consciously overcome our prejudices and that all the inhabitants of Slovenia need to develop intercultural competences (citizens and those who do not have citizenship (yet), natives and immigrants). There are also three suggested activities for teachers to help them respond to the growing intolerance and the intensification of prejudices against immigrant children (including both economic migrants and asylum seekers) in the educational process: 1) self-study (seeking information and training teachers about migration as a continuous process, prejudices, the conditions in the countries the children come from and Slovenians around the world), 2) teaching students (intercultural lessons, intercultural events, sometimes in cooperation with parents and local organizations, together with the migrants themselves), and 3) dissemination of activities so that information about the active engagement of teachers contributing to an intercultural society is spread, 
exchanged and developed. Teachers need knowledge about how to overcome prejudices, how to include and how to teach in a truly diverse society so they can participate as active citizens in their work environment.

Teachers can gain a lot of knowledge about the development of intercultural education on their own or for example through the project Only (With) Others Are We - but we will achieve greater effectiveness if they receive support from the Ministry of Education, Science and Sport with full-time employed teachers who support the inclusion of migrant children, instead of temporary projects, and content included in academic programmes, multiperspective syllabuses and teaching materials (multiperspective curricula) in which concrete learning objectives and teaching content would encourage them to tackle such topics in the educational process.

\section{REFERENCES}

Al Dolejmi, Ahmed Shihab Hammood (2017). Slovensko-angleško-arabski slovar za uporabo v šoli. Logatec: Osnovna šola 8 talcev.

Andreev, Svetlozar A. (2007). Slovenia. European immigration: A Sourcebook (eds. Anna Triandafyllidou, Ruby Gropas). Farnham, Burlington: Ashgate, 307-319.

Banjac, Živko (2015). Učenci priseljenci iz drugih držav v slovenskem šolskem sistemu. Branje združuje: z BDS že 20 let:Zbornik Bralnega društva Slovenije (ed. Veronika Rot Gabrovec). Ljubljana: Zavod Republike Slovenije za šolstvo, 17-24.

Bennett, Christine I. (2011). Comprehensive Multiculural Education, Theory and Practice. Boston: Allyn and Bacon.

Bešter, Romana, Medvešek, Mojca (2016). Medkulturne kompetence učiteljev: Primer poučevanja romskih učencev = Intercultural Competence of Teachers: The Case of Teaching Roma Students. Sodobna pedagogika 67/2, 26-45.

Bešter Turk, Marja (2011). Sporazumevalna zmožnost - eden izmed temeljnih ciljev pouka slovenščine. Jezik in slovstvo 56/3-4, 111-130.

Boecker, Malte C. (2008). Intercultural Competence - The Key Competence in the $21^{\text {st }}$ century? Bertelsmann Stiftung and Fondazione Cariplo, https://www.ngobg.info/ bg/documents/49/726bertelsmanninterculturalcompetences.pdf (5. 12. 2017).

Budinoska, Ines (2013). Ali osnovnošolski učitelji aktivno vključujejo učence priseljence v pouk? Jezik in slovstvo 58/3, 75-88.

Castles, Stephen, Miller, Mark J. (2009). The Age of Migration: International Population Movements in the Modern World. New York: Guilford Press.

Dimkovska, Lidija (ed.) (2014). Iz jezika v jezik: Antologija sodobne manjšinske in priseljenske književnosti na Slovenskem. Ljubljana: Društvo slovenskih pisateljev.

Drnovšek, Marjan (2012). Slovenski izseljenci in Zahodna Evropa v obdobju prve Jugoslavije. Ljubljana: Založba ZRC, ZRC SAZU.

Geda, Fabio (2012). In the Sea There Are Crocodiles. New York: Anchor Books. 
Grant, Carl A., Sleeter, Christine (2007). Doing Multicultural Education for Achievement and Equity. New York, London: Routledge.

Gruden, Saška Aleksandra (2016). Preseganje rasizma v socialno-pedagoških kontekstih. Radio Slovenija, Ars humana, guests Marijanca Ajša Vižintin, Goran Popović and Ksenija Šabec, http://4d.rtvslo.si/arhiv/ars-humana/174410995 (21. 10. 2017).

Hill, Richard (2002). We Europeans. Brussels: Europublic.

Huber, Josef (ed.) (2012). Intercultural Competence for All: Preparation for Living in a Heterogeneous World. Strasbourg: Council of Europe.

Izobraževalni programi. Opismenjevanje v slovenščini za odrasle govorce drugih jezikov: (z dodatkom za mladoletnike - prosilce za mednarodno zaščito) (2016). Ljubljana: Andragoški center Slovenije, http://arhiv.acs.si/programoteka/Opismenjevanje_v_slovenscini_za_odrasle_govorce_drugih_jezikov.pdf (5. 12. 2017).

Izzivi medkulturnega sobivanja (2016-2021). ISA institut, Osnovna šola Koper, http:// www.medkulturnost.si/ (21. 10. 2017).

Kentrić, Samira (2015). Balkanalije: Odraščanje v času tranzicije. Ljubljana: Beletrina.

Kržišnik Bukić, Vera, Josipovič, Damir (eds.) (2014). Zgodovinski, politološki, pravni in kulturološki okvir za definicijo narodne manjšine v Republiki Sloveniji. Ljubljana: Inštitut za narodnostna vprašanja.

Le z drugimi smo / Only (with) Others Are we (2016-2021). ZRC SAZU, Pedagoški inštitut, https://lezdrugimismo.si/ (19. 3. 2017).

Lukšič Hacin, Marina (2016). Theorizing the Concept of Multiculturalism through TayIor's 'Politics of Recognition'. Dve domovini / Two Homelands 44, 79-91.

Luthar, Breda (2017). Begunci in odmevi: Epistemologija konvencij. Dve domovini / Two Homelands 45, 153-168.

Merkeš, Janez (2015). Dvojna merila povsod povzročajo ogromno škode: Intervju z Ahmedom Pašićem. Delo, sobotna priloga, 24. januar 2015, 4-6.

Mikolič, Vesna (2016). Ethnic Identity and Intercultural Awareness in Modern Language Teaching: Tilka Model for Ethnic Conflicts Avoidance. Hauppauge (N. Y.): Nova Science Publishers.

Milharčič Hladnik, Mirjam (2015). Kultura mešanosti v nacionalnem in migracijskem kontekstu. Annales, Series Historia et Sociologia 25/1, 171-182.

Milharčič Hladnik, Mirjam (2016). Nadzor nad nadzorom: Strategije upiranja in avtonomnost delovanja migrantk v sodobni in zgodovinski perspektivi. Dve domovini / Two Homelands 43, 35-46.

Nieto, Sonia, Bode, Patty (2008). Affirming Diversity: The Sociopolitical Context of Multicultural Education. Boston: Allyn \& Bacon.

Pajnik, Mojca (2017). Medijsko-politični paralelizem: Legitimizacija migracijske politike na primeru komentarja v časopisu Delo. Dve domovini / Two Homelands 45, 169-184.

Peček, Mojca, Lesar, Irena (2006). Pravičnost slovenske šole: Mit ali realnost. Ljubljana: Sophia. 
Peček, Mojca, Skubic Ermenc, Klara (2016). Educating Teachers to Teach in Culturally and Linguistically Heterogeneous Classrooms. Sodobna pedagogika 67/2, 8-25.

Petrovčič, Peter (2016). “Učitelj mora pomagati otroku ne glede na vse. Ker ko dobite takšno mlado bitje, to bitje ni krivo niti za vojne niti za politiko niti za ravnanje staršev. Smo ljudje ali nismo?" Goran Popović, ravnatelj šole z učenci 32 različnih narodnosti. Mladina 14, 8. april 2016, 40-45.

Poročilo za opismenjevanje za mladoletnike brez spremstva (2017). Javni zavod Cene Štupar - Center za izobraževanje, Ljubljana, https://www.cene-stupar.si/wp-content/uploads/2017/06/POROCILO-ZA-OPISMENJEVANJE-ZA-MLADOLETNIKE-BREZ-SPREMSTVA-splet.pdf (5. 12. 2017).

Portera, Agostino (2011). Intercultural and Multicultural Education: Epistemological and Semantic Aspects. Intercultural and Multicultural Education: Enhancing Global Interconnectedness (eds. Carl A. Grant, Agostino Portera). New York, Oxon: Routledge, 12-30.

Rey-von Allmen, Micheline (2011). The Intercultural Perspective and Its Development through Cooperation with the Council of Europe. Intercultural and Multicultural Education: Enhancing Global Interconnectedness (eds. Carl A. Grant, Agostino Portera). New York, Oxon: Routledge, 33-48.

Scheffer, Paul (2011). Immigrant Nations. Cambridge, Malden: Polity Press.

Sedmak, Mateja (2015). (Mešane) kulturne identitete: Konstrukcija in dekonstrukcija. Annales, Series Historia et Sociologia 25/1, 155-170.

Sedmak, Mateja, Medarić, Zorana (2017). Life Transitions of the Unaccompanied Migrant Children in Slovenia: Subjective Views. Dve domovini / Two Homelands 45, 61-77.

Migration changes, Slovenia, 2014, Statistical Office of the Republic of Slovenia, http:// www.stat.si/StatWeb/en/News/Index/5318 (21. 10. 2017).

Skubic Ermenc, Klara (2007). Interkulturnost v učnih načrtih slovenske osnovne šole. Pedagoška obzorja 22/1-2, 128-135.

Skubic Ermenc, Klara (2010). Med posebnimi pravicami in načelom interkulturnosti. Sodobna pedagogika 2, 268-279.

Socioeconomic Characteristics of International Migrants, 2013, Slovenia, Statistical Office of the Republic of Slovenia, http://www.stat.si/StatWeb/en/News/Index/4772 (21. 10. 2017).

Statistični podatki o tujcih v Sloveniji $(2015,2016)$. MNZ za vas, Tujci v Sloveniji, Statistika, http://www.mnz.gov.si/si/mnz_za_vas/tujci_v_sloveniji/statistika/ (21. 10. 2017).

Šabec, Ksenija (2006). Homo europeus: Nacionalni stereotipi in kulturna identiteta Evrope. Ljubljana: Fakulteta za družbene vede.

Šabec, Ksenija (2016). Slovenski učbeniki kot akter etnocentrične in rasistične socializacije: Primer osnovnošolskih učbenikov za geografijo. Dve domovini / Two Homelands 44, 139-152. 
Šlibar, Neva (ed.) (2006). Barve strpnosti, besede drugačnosti, podobe tujosti: Vzgoja za strpnost in sprejemanje drugačnosti preko mladinske književnosti. Ljubljana: Center za pedagoško izobraževanje, Filozofska fakulteta.

Ule, Mirjana (2005). Psihologija komuniciranja. Ljubljana: Fakulteta za družbene vede. Vižintin, Marijanca Ajša (2014). Model medkulturne vzgoje in izobraževanja: Za uspešnejše vključevanje otrok priseljencev. Dve domovini / Two Homelands 40, 71-89.

Vižintin, Marijanca Ajša (2015). Interculturality as a Principle and the Cooperation of School with the Local Environment. Learning and Education in Community: The Role of Schools and Community Organisations = Učenje in izobraževanje v skupnosti: Vloga šole in skupnostnih organizacij (eds. Marko Radovan, Marek Kościelniak). Ljubljana: Znanstvena založba Filozofske fakultete = University Press, Faculty of Arts, 115-135.

Vižintin, Marijanca Ajša (2016). (Im)migrant and Ethnic Minority Literature in Education Curricula in Slovenia. CLCWeb (Comparative Literature and Culture) 18/1, http://docs.lib.purdue.edu/clcweb/vol18/iss1/7/ (21. 10. 2017).

Vižintin, Marijanca Ajša (2017). Medkulturna vzgoja in izobraževanje: Vključevanje otrok priseljencev. Ljubljana: Založba ZRC SAZU.

Vrečer, Natalija (2011). Medkulturne kompetence kot prvi pogoj za uspešen medkulturni dialog. Medkulturni odnosi kot aktivno državljanstvo (eds. Marina Lukšič Hacin, Mirjam Milharčič Hladnik, Mitja Sardoč). Ljubljana: Založba ZRC SAZU, 169-179.

White Paper in Intercultural Dialogue: Living Together as Equals in Dignity (2008). Strasbourg: Council of Europe, https://www.coe.int/t/dg4/intercultural/Source/Pub_ White_Paper/White\%20Paper_final_revised_EN.pdf (21. 10. 2017).

Yousafzai, Malala, Lamb, Christina (2013). I Am Malala: The Girl Who Stood Up for Education and Was Shot by the Taliban. London: Little, Brown and Company.

Žitnik Serafin, Janja (2012). Bridges and Walls: Slovenian Multiethnic Literature and Culture. Frankfurt am Main: P. Lang.

Žitnik Serafin, Janja (2014). Migrantske in manjšinske medkulturne vsebine v učnih gradivih za slovenski jezik in književnost. Vzgajati k različnosti: Interdisciplinarna primerjalna raziskava med Italijo in Slovenijo (eds. Norina Bogatec, Nives Zudič Antonič). Koper = Capodistria: Univerza na Primorskem, Znanstveno-raziskovalno središče, Univerzitetna založba Annales, 213-228.

Žitnik Serafin, Janja (ed.) (2015). Slovensko izseljenstvo v luči otroške izkušnje. Ljubljana: Založba ZRC, ZRC SAZU.

Žitnik Searfin, Janja, Kalc, Aleksej (eds.) (2017). Raziskovanje slovenskega izseljenstva: Vidiki, pristopi, vsebine. Ljubljana: Založba ZRC. 


\section{POVZETEK}

\section{RAZVOJ MEDKULTURNE VZGOJE IN IZOBRAŽEVANJA Marijanca Ajša VIŽINTIN}

Avtorica v prispevku navaja nekaj primerov dobrih praks iz slovenskih šol na področju razvoja medkulturne vzgoje in izobraževanja ter predlaga dejavnosti za aktivno delovanje učiteljev: 1) samoučenje (o migracijah kot stalnem procesu, predsodkih, Slovencih po svetu, o razmerah v državah, iz katerih prihajajo otroci); 2) poučevanje učencev (medkulturne ure, medkulturne prireditve v sodelovanju s priseljenci), vključujoč v posamezne dejavnosti starše in lokalno skupnost; ter 3) diseminacijo dejavnosti. Tudi slednja dejavnost je pomembna, da se informacije o aktivnem delovanju učiteljev, ki prispevajo k medkulturni družbi, širijo, izmenjujejo in nadgrajujejo. Učitelji bi bili pri svojem delu uspešnejši in bolj strokovno usposobljeni, če bi vsebine o raznoliki družbi in poučevanju $v$ njej vnesli tudi $v$ učne načrte, $v$ učno gradivo ter v študijske programe na pedagoških in filozofskih fakultetah. 